\title{
Use of data processing for rapid detection of the prostate-specific antigen biomarker using immunomagnetic sandwich-type sensors
}

\author{
Camila A. Proença ${ }^{1}$, Tayane A. Freitas ${ }^{1}$, Thaísa A. Baldo ${ }^{1}$, Elsa M. Materón ${ }^{1,2}$, \\ Flávio M. Shimizu ${ }^{2,3}$, Gabriella R. Ferreira ${ }^{4}$, Frederico L. F. Soares ${ }^{1,5}$, Ronaldo C. Faria ${ }^{* 1}$ \\ and Osvaldo N. Oliveira Jr. ${ }^{* 2}$
}

\author{
Full Research Paper \\ Address: \\ ${ }^{1}$ Chemistry Department, Federal University of São Carlos, CP 676, \\ São Carlos 13565-905, São Paulo, Brazil, ${ }^{2}$ São Carlos Institute of \\ Physics, University of São Paulo, CP 369, São Carlos 13560-970, \\ São Paulo, Brazil, ${ }^{3}$ Brazilian Nanotechnology National Laboratory \\ (LNNano), Brazilian Center for Research in Energy and Materials \\ (CNPEM), Campinas 13083-970, São Paulo, Brazil, ${ }^{4}$ Carlos Institute \\ of Chemistry, University of São Paulo, São Carlos 13560-970, São \\ Paulo, Brazil and ${ }^{5}$ Chemistry Department, Federal University of \\ Paraná, Curitiba, 81531-980, Paraná, Brazil

\section{Email:} \\ Ronaldo C. Faria* - rcfaria@ufscar.br; Osvaldo N. Oliveira Jr." - \\ chu@ifsc.usp.br \\ * Corresponding author

\section{Keywords:} \\ cancer biomarkers; magnetite nanoparticles; microfluidic devices; \\ nanoarchitectonics; information visualization; sandwich-type \\ immunosensors; screen-printed electrodes \\ Beilstein J. Nanotechnol. 2019, 10, 2171-2181. \\ doi:10.3762/bjnano.10.210 \\ Received: 02 August 2019 \\ Accepted: 07 October 2019 \\ Published: 06 November 2019 \\ creation of functional materials and systems". \\ Guest Editor: K. Ariga \\ (C) 2019 Proença et al.; licensee Beilstein-Institut. \\ License and terms: see end of document.
}

Open Access

This article is part of the thematic issue "Nanoarchitectonics: bottom-up

\begin{abstract}
Diagnosis of cancer using electroanalytical methods can be achieved at low cost and in rapid assays, but this may require the combination with data treatment for determining biomarkers in real samples. In this paper, we report an immunomagnetic nanoparticlebased microfluidic sensor (IN $\mu$-SPCE) for the amperometric detection of the prostate-specific antigen (PSA) biomarker, the data of which were treated with information visualization methods. The IN $\mu$-SPCE consists of eight working electrodes, reference and counter electrodes. On the working electrodes, magnetic nanoparticles with secondary antibodies with the enzyme horseradish peroxidase were immobilized for the indirect detection of PSA in a sandwich-type procedure. Under optimal conditions, the immunosensor could operate within a wide range from 12.5 to $1111 \mathrm{fg} \cdot \mathrm{L}^{-1}$, with a low detection limit of $0.062 \mathrm{fg} \cdot \mathrm{L}^{-1}$. Multidimensional projections combined with feature selection allowed for the distinction of cell lysates with different levels of PSA, in agreement with results from the traditional enzyme-linked immunosorbent assay. The approaches for immunoassays and data processing are generic, and therefore the strategies described here may provide a simple platform for clinical diagnosis of cancers and other types of diseases.
\end{abstract}




\section{Introduction}

The prostate-specific antigen (PSA) used in clinical diagnosis is present in normal prostatic secretions, but its concentration is often elevated in prostate cancer patients. In spite of its lack of specificity, PSA screening has contributed to a significant decline $(45-70 \%)$ in prostate cancer mortality since the early 1990s [1]. To identify cancer biomarkers and to develop methodologies to quantify them at low cost is critical for early cancer diagnostics, while it also helps to understand cancer diseases [1]. Protein biomarkers are commonly measured using conventional immunoassays such as enzyme-linked immunosorbent assay (ELISA) [1], radioimmunoassay (RIA) [2], fluorescence methods [3], and chemiluminescence [4]. Unfortunately, these standard methodologies have high cost, long analysis times (around $18 \mathrm{~h}$ ) and require pretreatment of samples $[5,6]$. Other approaches to produce immunosensors have therefore been studied, including electroanalytical methods $[7,8]$ in which antibodies or antigens are immobilized on a suitable matrix and the specific antigen-antibody recognition leads to an electrical or electrochemical signal.

The choice of the molecular architecture for the electrochemical immunosensors is crucial for obtaining high sensitivity and specificity. The matrix on which the bioactive layer is deposited may contain metallic nanoparticles to enhance the electrochemical response [8,9], including magnetic nanoparticles (MNPs) that can be exploited for their catalytic properties [10] and magnetic separation in pre-concentrating the analyte [11-16]. The most common magnetic nanoparticles used for this purpose are magnetite $\left(\mathrm{Fe}_{3} \mathrm{O}_{4}\right)$ nanoparticles, which have a stronger magnetism than other iron oxide nanoparticles [17]. These MNPs can be synthesized through various techniques, such as ultrasound irradiation, sol-gel methods, thermal decomposition, and co-precipitation [18-21]. In addition, they can be modified with biomolecules and other compounds to improve the sensing performance. Electrochemical immunosensors containing magnetic nanoparticles have been used to detect several cancer biomarkers [22-24]. Zhuo and co-workers detected carcinoembryonic antigen (CEA) and $\alpha$-fetoprotein (AFP) with a three-layer immunosensor with $\mathrm{Fe}_{3} \mathrm{O}_{4}$ magnetic core modified with a Prussian blue (PB) interlayer and a gold shell. The enzymes horseradish peroxidase and glucose oxidase were immobilized to improve sensitivity, with linear ranges between 0.01 and $80.0 \mathrm{ng} \cdot \mathrm{mL}^{-1}$ for CEA and from 0.014 to $142 \mathrm{ng} \cdot \mathrm{mL}^{-1}$ for $\mathrm{AFP}$, and detection limits of $4 \mathrm{pg} \cdot \mathrm{mL}^{-1}$ and $7 \mathrm{pg} \cdot \mathrm{mL}^{-1}$, respectively [25]. PSA and interleukin 6 (IL-6) were measured with a microfluidic electrochemical immunoassay system, in which commercial magnetic particles were conjugated with secondary antibodies and horseradish peroxidase (HRP) [26]. These immunomagnetic nanoparticle-based microfluidic sensors with screen-printed carbon electrodes (IN $\mu$-SPCEs) showed limits of detection of $0.23 \mathrm{pg} \cdot \mathrm{mL}^{-1}$ for PSA and $0.30 \mathrm{pg} \cdot \mathrm{mL}^{-1}$ for IL-6, measured in the serum of prostate cancer patients [26]. Immunosensors to detect PSA include magnetic nanoparticles modified with gold [27], nitrodopamine functionalized iron oxide nanoparticles [3,28], ferrocene [28] and others [29,30].

A major challenge regarding the use of immunosensors in real samples lies in the difficulty to analyze considerable amounts of data in a single analysis, especially owing to the expected variability of blood serum, saliva, urine and tissue samples. This has sparked interest in computational tools [31]. For instance, information visualization techniques have been used to enhance the distinguishing ability of biosensors [32-34]. Discrimination of blood serum samples from patients with distinct probability to develop pancreatic cancer was made possible with a multidimensional projection technique applied to immunosensing data [34]. In this paper, we describe an IN $\mu$-SPCE to detect PSA using amperometry. To the best of our knowledge, the limit of detection is the lowest in the literature. The high sensitivity is probably connected to the molecular architecture of the sensing device, in which polyclonal antibodies were immobilized onto magnetic nanoparticles to selectively capture PSA. Furthermore, a proof-of-principle experiment regarding the detection of PSA in healthy and prostate cancer cell lysates is demonstrated, where the data were discriminated using multidimensional projections within the PEx-Sensors software [32].

\section{Results and Discussion Analytical performance}

The analytical performance of the IN $\mu$-SPCEs was evaluated using PSA standard solutions in PBS at concentrations ranging from 12.5 to $1111 \mathrm{fg} \cdot \mathrm{mL}^{-1}$. After capturing PSA with the bioconjugate $\left(\mathrm{Ab}_{2}\right.$-MNP-HRP) from the standard solution, $100 \mu \mathrm{L}$ were injected into the microfluidic channel using an injection valve, and then incubated for $30 \mathrm{~min}$ on an anti-PSAAuNP-SPCE surface. A sandwich-type structure was assembled following the incubation. The amperometric analytical signal was obtained using constant-potential amperometry at a working electrode potential of $-200 \mathrm{mV}$ vs pseudo-reference $\mathrm{Ag} / \mathrm{AgCl}$. The mixed solution containing $\mathrm{H}_{2} \mathrm{O}_{2}\left(1 \mu \mathrm{mol} \cdot \mathrm{L}^{-1}\right)$ and hydroquinone (HQ, $10 \mu \mathrm{mol} \cdot \mathrm{L}^{-1}$ ) was injected into the electrochemical cell, and the signal was monitored. The HRP$\mathrm{Fe}(\mathrm{III})$ immobilized on the MNPs was oxidized by $\mathrm{H}_{2} \mathrm{O}_{2}$ to form an intermediate $\left(\mathrm{Fe}^{4+}=\mathrm{O}\right)$ and a porphyrin $\pi$-cation radical. The oxidized HRP was reduced by the mediator hydroquinone (HQ) forming benzoquinone (BQ), which was electrochemically reduced by accepting one electron from the electrode, with the enzyme returning to its native form. Figure 1A shows the cathodic peak current responses, with a linear dependence of the current on the logarithm of the PSA concentration 

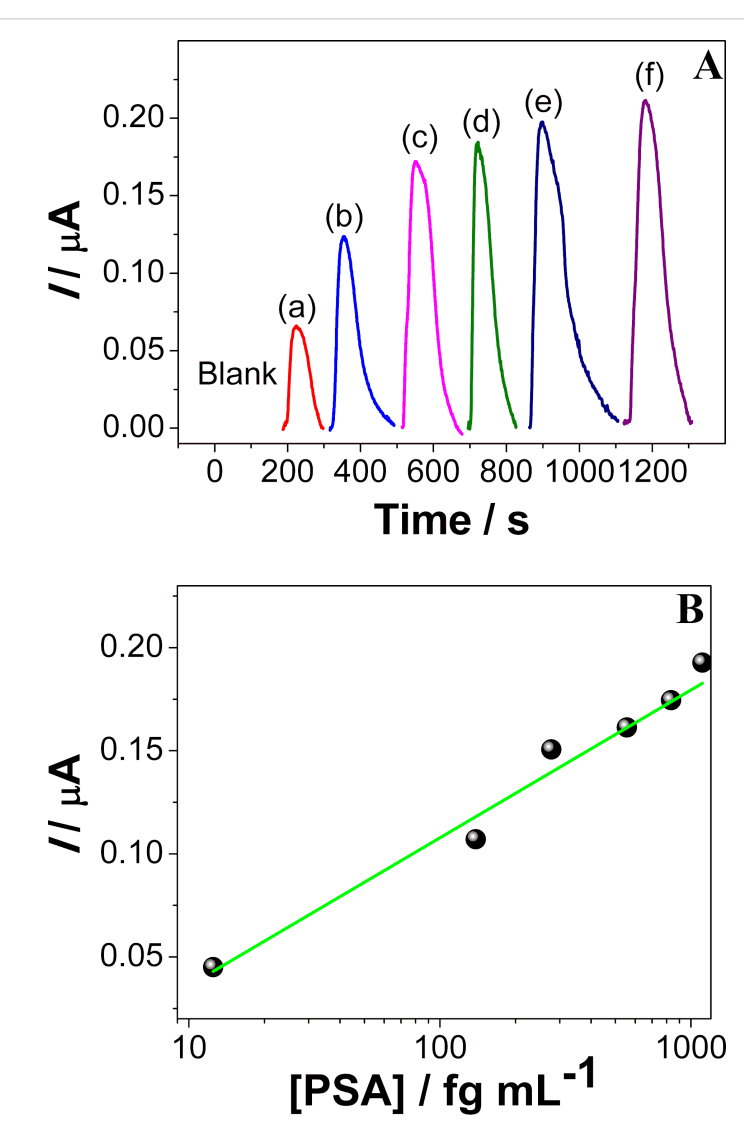

Figure 1: (A) Amperometric responses for a blank solution and PSA solutions at concentrations of: (a) 12.5, (b) 138, (c) 277, (d) 555 , (e) 823 and (f) $1111 \mathrm{fg} \cdot \mathrm{mL}^{-1}$ prepared in a calf serum medium. (B) Analytical curve for PSA standards, using MNPs, anti-Ab $b_{1}$ and anti-Ab 2 at a concentration of $10 \mu \mathrm{g} \cdot \mathrm{mL}^{-1}$, and concentrations of $10 \mu \mathrm{mol} \cdot \mathrm{L}^{-1}$ and $1 \mu \mathrm{mol} \cdot \mathrm{L}^{-1}$ for $\mathrm{HQ}$ and $\mathrm{H}_{2} \mathrm{O}_{2}$, respectively.

in Figure $1 \mathrm{~B}$, according to the linear regression equation: $I(\mathrm{nA})=1.03 \cdot 10^{-6}+7.2 \cdot 10^{-8} \log (x)$. The detection limit calculated using the IUPAC method [35,36] in Equation 1 is $0.062 \mathrm{fg} \cdot \mathrm{mL}^{-1}$ :

$$
\mathrm{LD}=\frac{3 \cdot \mathrm{SD}}{\text { slope }},
$$

where SD and slope are the standard deviation and slope of the calibration curve, respectively. To our knowledge, this limit of detection is the lowest found in the literature for immunosensors to detect PSA. The high sensitivity could be attributed to the use of MNPs (see characterization in Figure S1, Supporting Information File 1) decorated with Ab2 and HRP, which allowed for the capture, separation, and preconcentration of the analyte. It helped to acquire an amplified signal response and assisted the binding capacity of the antibody and antigen covalently immobilized on the electrode surface. Also, the monoclonal antibody provides high specificity to a single epitope, which is reflected in a low cross-reactivity. A comparison of various sandwich-type immunosensors and immunoassays for detection of PSA in the literature is presented in Table 1.

Repeatability is a significant parameter for immunosensors. It was checked by using eight working electrodes in an array prepared under the same conditions, with the electrochemical response obtained at a given PSA concentration. The relative standard deviation in percent varied from $6 \%$ to $9 \%$, with similar electrochemical responses for all immunosensors.

The detection mechanism for the immunosensors is likely an adsorption process, which is common for this type of sensor. We verified this hypothesis by modeling the amperometric responses for PSA antigen at concentrations from 12.5 to $1111 \mathrm{fg} \cdot \mathrm{mL}^{-1}$ in Figure 2, where a Langmuir-Freundlich equation (Equation 2) was used to fit the data:

$$
q=\frac{Q_{m}\left(K_{\mathrm{a}} C_{\mathrm{eq}}\right)^{n}}{\left(K_{\mathrm{a}} C_{\mathrm{eq}}\right)^{n}+1}
$$

where $Q_{m}$ is the adsorption capacity in $\mathrm{nA}, K_{\mathrm{a}}$ is the adsorption affinity constant in milliliter per femtogram, $C_{\text {eq }}$ is the concentration of the analyte in solution and $n$ is a dimensionless index of heterogeneity, which varies between 0 and 1 for heterogeneous materials ( $n=1$ for homogeneous materials) [54]. Figure 2 shows the results with saturation of available sites with $Q_{m}=339.85 \pm 32.15 \mathrm{nA}$, which corresponds to ca. $64.4 \mathrm{fg} \cdot \mathrm{mL}^{-1}, n=0.42 \pm 0.08$ and an affinity constant $\left(K_{\mathrm{a}}=0.45 \pm 0.09 \mathrm{~mL} \cdot \mathrm{fg}^{-1}\right)$ characteristic of a polymer-based immunosensor [34,55]. This rather low value is expected for biosensors where the index $n$ is characteristic of heterogeneous adsorption with polyclonal biomolecules that have many active sites with different degrees of affinity and selectivity.

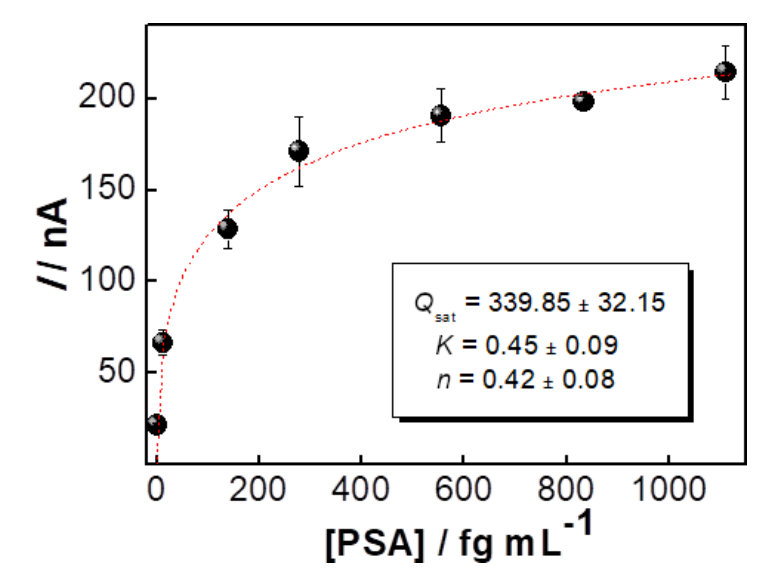

Figure 2: Peak current as a function of the PSA concentration fitted with a Langmuir-Freundlich equation (dashed line). 


\begin{tabular}{|c|c|c|c|}
\hline measurement method & linear range & detection limit & reference \\
\hline amperometry & $2-15 \mathrm{ng} \mathrm{mL}^{-1}$ and $15-120 \mathrm{ng} \mathrm{mL}^{-1}$ & $1.1 \mathrm{ng} \cdot \mathrm{mL}^{-1}$ & {$[37]$} \\
\hline electrochemical impedance spectroscopy (EIS) & $1-100 \mathrm{pg} \cdot \mathrm{mL}^{-1}$ & $1 \mathrm{pg} \cdot \mathrm{mL}^{-1}$ & [38] \\
\hline linear sweep voltammetry (LSV) & $1-35 \mathrm{ng} \cdot \mathrm{mL}^{-1}$ & $0.76 \mathrm{pg} \cdot \mathrm{mL}^{-1}$ & [39] \\
\hline LSV & $1-10 \mathrm{ng} \cdot \mathrm{mL}^{-1}$ & $1 \mathrm{ng} \cdot \mathrm{mL}^{-1}$ & {$[40]$} \\
\hline chemiluminescence & $0.74 \mathrm{pg} \cdot \mathrm{mL}^{-1}$ to $0.74 \mu \mathrm{g} \cdot \mathrm{L}^{-1}$ & $0.7 \mathrm{pg} \cdot \mathrm{mL}^{-1}$ & {$[41]$} \\
\hline amperometry & $0-60 \mu \mathrm{g} \cdot \mathrm{L}^{-1}$ & $0.08 \mu \mathrm{g} \cdot \mathrm{L}^{-1}$ & [5] \\
\hline surface plasmon resonance & $1-100 \mathrm{ng} \cdot \mathrm{mL}^{-1}$ & $1 \mathrm{ng} \cdot \mathrm{mL}^{-1}$ & {$[42]$} \\
\hline chronoamperometry & $1 \times 10^{-5} \mathrm{ng} \cdot \mathrm{mL}^{-1}$ to $100 \mathrm{ng} \cdot \mathrm{mL}^{-1}$ & $0.002 \mathrm{pg} \cdot \mathrm{mL}^{-1}$ & [43] \\
\hline amperometry & $50 \mathrm{fg} \cdot \mathrm{mL}^{-1}$ to $40 \mathrm{ng} \cdot \mathrm{mL}^{-1}$ & $16.6 \mathrm{fg} \cdot \mathrm{mL}^{-1}$ & [44] \\
\hline EIS & $1 \mathrm{pg} \cdot \mathrm{mL}^{-1}$ to $100 \mathrm{ng} \cdot \mathrm{mL}^{-1}$ & $1 \mathrm{pg} \cdot \mathrm{mL}^{-1}$ & {$[45]$} \\
\hline EIS & $0-10 \mathrm{ng} \cdot \mathrm{mL}^{-1}$ & $590 \mathrm{pg} \cdot \mathrm{mL}^{-1}$ & {$[46]$} \\
\hline EIS & $0.05-5 \mathrm{ng} \cdot \mathrm{mL}^{-1}$ & $13 \mathrm{pg} \cdot \mathrm{mL}^{-1}$ & {$[47]$} \\
\hline EIS & $0.01-10 \mathrm{ng} \cdot \mathrm{mL}^{-1}$ & $2 \mathrm{pg} \cdot \mathrm{mL}^{-1}$ & {$[48]$} \\
\hline chip enzyme immunoassay & $3.2-50 \mathrm{ng} \cdot \mathrm{mL}^{-1}$ & $3.2 \mathrm{ng} \cdot \mathrm{mL}^{-1}$ & [49] \\
\hline electrochemical chemiluminescence (ECL) & $0.0001-100 \mathrm{ng} \cdot \mathrm{mL}^{-1}$ & $0.1 \mathrm{pg} \cdot \mathrm{mL}^{-1}$ & {$[50]$} \\
\hline differential pulse voltammetry (DPV) & $0.001-5 \mathrm{ng} \cdot \mathrm{mL}^{-1}$ & $0.31 \mathrm{pg} \cdot \mathrm{mL}^{-1}$ & {$[51]$} \\
\hline EIS & $0.5 \mathrm{pg} \cdot \mathrm{mL}^{-1}$ to $35 \mathrm{ng} \cdot \mathrm{mL}^{-1}$ & $5 \mathrm{pg} \cdot \mathrm{mL}^{-1}$ & [52] \\
\hline DPV & $0.1 \mathrm{pg} \cdot \mathrm{mL}^{-1}$ to $90 \mathrm{ng} \cdot \mathrm{mL}^{-1}$ & $10 \mathrm{fg} \cdot \mathrm{mL}^{-1}$ & {$[52]$} \\
\hline DPV & $0.2-40 \mathrm{ng} \cdot \mathrm{mL}^{-1}$ & $0.020 \mathrm{ng} \cdot \mathrm{mL}^{-1}$ & [53] \\
\hline amperometry & $12.5-1111 \mathrm{fg} \cdot \mathrm{mL}^{-1}$ & $0.062 \mathrm{fg} \cdot \mathrm{mL}^{-1}$ & this work \\
\hline
\end{tabular}

\section{Application of the immunosensor in real samples}

The suitability of IN $\mu$-SPCEs for detecting PSA in real samples was tested with malignant (LNCap) and non-malignant (PNT-2) cells. In contact with cell lysates containing several proteins, the bioconjugate binds specifically to PSA (PSA-Ab 2 -MNP-HRP), thus allowing for the capture, separation and preconcentration of PSA employing a magnet. Furthermore, detection is enhanced because of the presence of multiple immobilized HRP molecules. Figure 3 shows that a high amount of PSA is found in LNCap in comparison to PNT-2 using the immunosensor, in agreement with the standard ELISA method. The limit of quantification with the immunosensor is lower than the threshold established for the serum level found in patients with prostate cancer (above $3.6 \mathrm{ng} \cdot \mathrm{mL}^{-1}$ stage A1) [56]. The samples were diluted in PBS for reaching the linear range, providing a response within the stipulated standards for the samples. Using the linear discrimination technique, the concentration is predicted for the real samples with $91.67 \%$ accuracy.

\section{Information visualization applied to the immunosensing data}

The sensitivity of the IN $\mu$-SPCEs could be exploited in distinguishing a diversity of samples by using multidimensional projection techniques. The whole amperograms in Figure 1A were processed with four multidimensional projection techniques, namely, principal component analysis (PCA), least

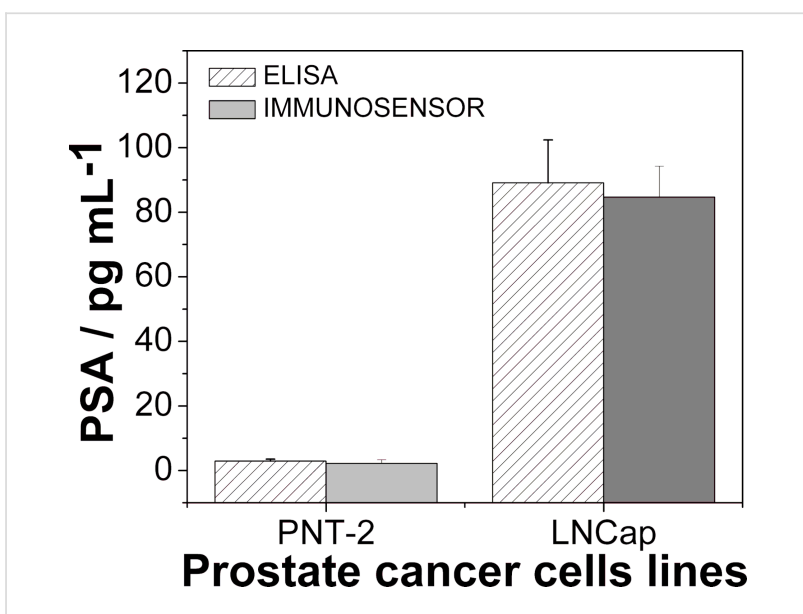

Figure 3: ELISA and IN $\mu$-SPCE results for PSA in control cell lysates (PNT-2) and prostate cancer cells (LNCap).

square projection (LSP), interactive document mapping (IDMAP) and Sammon's mapping (SM), and the silhouette coefficients, $S$, were calculated as summarized in Figure S2 (Supporting Information File 1). The samples can be discriminated very well in all cases because $S>0.71$ [46], and the highest value was obtained with the IDMAP technique. From the parallel coordinates (PC) plot in Figure S3 (Supporting Information File 1), we notice that the initial values for the current hamper discrimination, and therefore these dimensions (corresponding to times) are marked as red boxes (i.e., $S<0$ ) in 
the upper part of the map. To improve discrimination, we adopted a feature-selection procedure [22] that consists in eliminating the dimensions that hamper discrimination. Figure 4 shows the parallel coordinates plot after feature selection, which leads to clear discrimination where the dimensions all contribute to detection, as represented by the blue boxes (i.e., $S>0)$.

The maps obtained with the various multidimensional projection techniques after feature selection are shown in Figure S4 (Supporting Information File 1). The silhouette coefficients $S$ increased by about $20 \%$ in comparison to the values without feature selection. The $S$ value for IDMAP was calculated using the following equation:

$$
S_{\text {IDMAP }}=\frac{\delta\left(X_{i}, X_{j}\right)-\delta_{\min }}{\delta_{\max }-\delta_{\min }}-\delta\left(Y_{i}, Y_{j}\right),
$$

where the minimum and maximum distances between the concentration values are given as $\delta_{\min }$ and $\delta_{\max }$, respectively, and $\delta\left(X_{i}, X_{j}\right)$ is the Euclidean distance between current responses for the PSA concentrations $X_{i}$ and $X_{j}$ [32]. IDMAP was found to give the highest $S$ values and was used to project the data in Figure 5. One should note the large distance between the data points for PBS and those for the smallest concentration tested. This means that it is probably possible to detect PSA concentrations even lower than $12.5 \mathrm{fg} \cdot \mathrm{mL}^{-1}$. The projection is consistent with the PSA concentrations obtained with ELISA for PNT-2 and LNCap cells with values of 5 and $84-92 \mathrm{fg} \cdot \mathrm{mL}^{-1}$, respectively. This can be seen by the location of the sandwichtype immunosensing data for these cells in Figure 5.

\section{Conclusion}

In this paper, we leverage sensing technologies to achieve ultrahigh sensitivity in detecting the prostate cancer biomarker PSA by using MNPs to capture PSA in a pre-concentration proce-

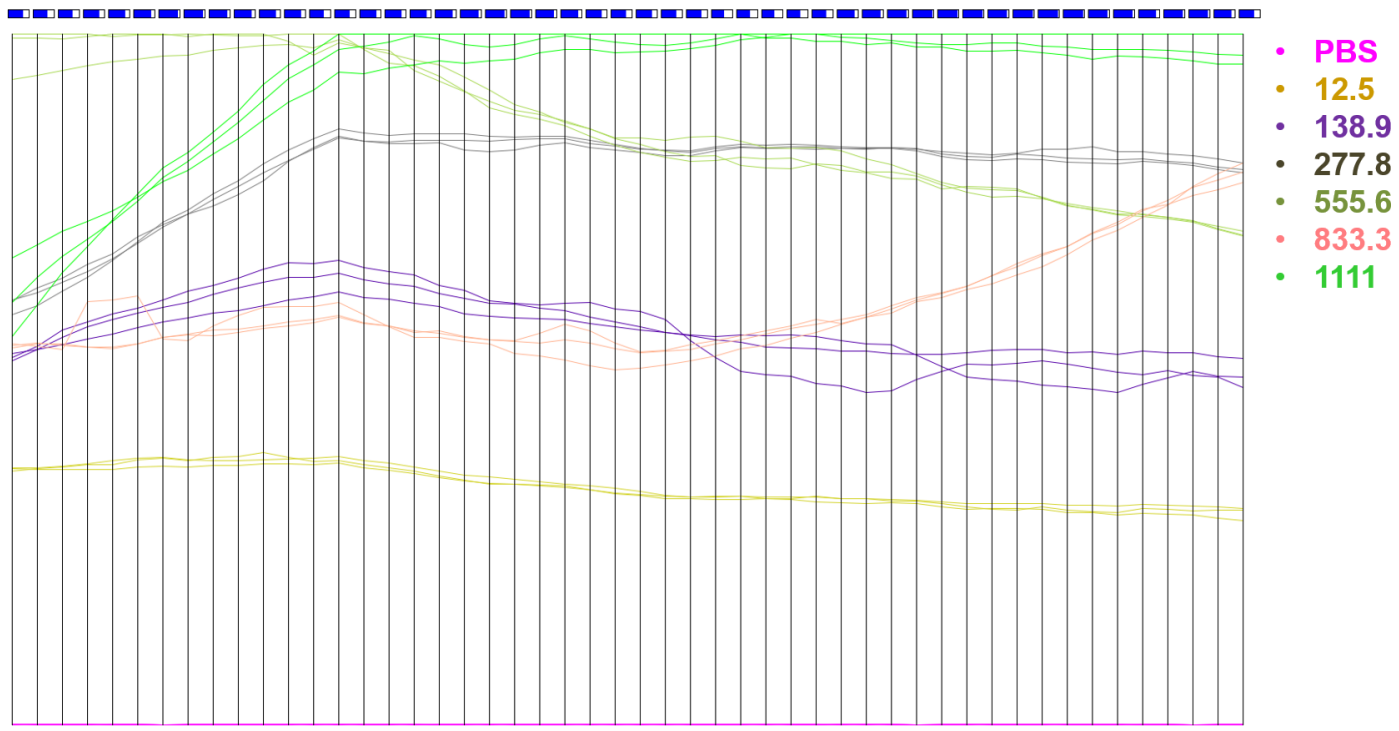

Figure 4: Parallel coordinates plot for PSA concentrations from 12.5 to $1111 \mathrm{fg} \cdot \mathrm{mL}^{-1}$ after the feature-selection procedure. The $x$-axis represents time values, while the $y$-axis represents Euclidean distances related to the current.

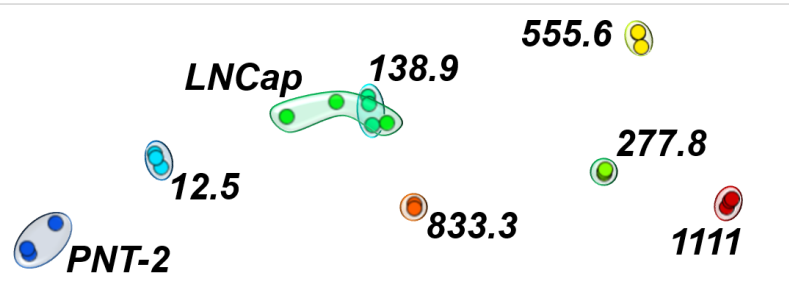

PBS

Figure 5: IDMAP plot obtained from the data in Figure 1A for buffers containing different PSA concentrations and from Figure 3 for prostate cancer cells. In both cases, feature selection was applied before plotting the data. 
dure for a sandwich-type immunomagnetic sensor. Electrochemical immunoassays with disposable microfluidic devices led to excellent linearity, reproducibility, and fast detection at low-cost, while showing excellent agreement with the standard method ELISA. Importantly, the approach for the immunoassays can be adapted for multiplex detection of biomarkers, in addition to PSA, by combining with other proteins. We also demonstrated that information visualization techniques, so far most commonly used for impedance spectroscopy sensing data, can be applied to amperometric results with a microfluidic sandwich-type immunosensor. The data processing allows for a more didactic interpretation of the results and improves separation between samples of patients with high levels of PSA from those who have lower concentrations.

\section{Experimental \\ Materials}

The reagents used were either of analytical or HPLC grade. Reduced L-glutathione (GSH, 99\%), bovine serum albumin (BSA), $\mathrm{HAuCl}_{4} \cdot 3 \mathrm{H}_{2} \mathrm{O}(99.9 \%)$, sodium borohydride (99\%), horseradish peroxidase (HRP, $M_{\mathrm{W}}=44000 ; 250-330 \mathrm{u} \cdot \mathrm{mg}^{-1}$ ), poly(diallydimethylammonium chloride) (PDDA, $20 \mathrm{wt} \%$ in $\mathrm{H}_{2} \mathrm{O}$ ), 1-(3-(dimethylamino)propyl)-3-ethylcarbodiimide hydrochloride (EDC), $\mathrm{N}$-hydroxysulfosuccinimide (Sulfo-NHS), hydrogen peroxide $\left(\mathrm{H}_{2} \mathrm{O}_{2}, 30 \%\right)$, Tween-20, and 2-(Nmorpholino)ethanesulfonic acid hydrate (MES) were purchased from Sigma-Aldrich. Monoclonal (mouse) primary anti-human prostate specific antigen (PSA) antibody, natural human prostate-specific antigen (PSA), and standard and secondary anti-PSA antibodies were obtained from Abcam, Cambridge,
UK. Graphite-based ink was obtained from Henkel Electrodag, USA (reference code 423SS), silver chloride ink was purchased from Gwent electronic materials Ltd., UK (Product code C2130905D3), the cell lines PNT-2 and LNCap were acquired from the Banco de Células do Rio de Janeiro (BCRJ) (Rio de Janeiro, Brazil). For the synthesis of magnetic nanoparticles, sodium hydroxide $(\mathrm{NaOH})$ with $97 \%$ purity and ferrous sulfate heptahydrate $\left(\mathrm{FeSO}_{4} \cdot 7 \mathrm{H}_{2} \mathrm{O}\right)$ with $\geq 99.6 \%$ purity were purchased from Vetec Química Fina Ltda (Rio de Janeiro, Brazil), and ferric chloride hexahydrate $\left(\mathrm{FeCl}_{3} \cdot 6 \mathrm{H}_{2} \mathrm{O}\right)$ with $\geq 98 \%$ purity was purchased from Sigma-Aldrich. Hydrochloric acid $(\mathrm{HCl}$, $36.5-38.0 \% \mathrm{w} / \mathrm{w}$ ) and $\mathrm{NaCl}$ with $99 \%$ purity were acquired from Labsynth (São Paulo, Brazil). Sodium citrate $\left(\mathrm{Na}_{3} \mathrm{C}_{6} \mathrm{H}_{5} \mathrm{O}_{7}\right)$ with $99.8 \%$ purity was purchased from J.T Baker Chemical Company. All aqueous solutions were prepared with ultrapure water $\left(18 \mathrm{M} \Omega \cdot \mathrm{cm}\right.$ at $\left.25^{\circ} \mathrm{C}\right)$ obtained from a Milli-Q Direct-0.3 (Millipore) purification system.

\section{Fabrication of sandwich-type electrochemical immunosensors}

The multi-channel screen-printed array of electrodes was fabricated according to the procedures established by Faria and collaborators [57]. The experimental details are given in Supporting Information File 1. The fabrication of this sandwichtype immunosensor comprises four steps, as depicted in Figure 6: (1) deposition of monoclonal antibody on the carbon electrode, (2) bioconjugate modification using HRP and polyclonal antibody, (3) capture of biomarker by the bioconjugate, (4) sandwich formation by injection of the biomarker captured by $\mathrm{Ab}_{2}$-MNP-HRP in the microfluidic system.

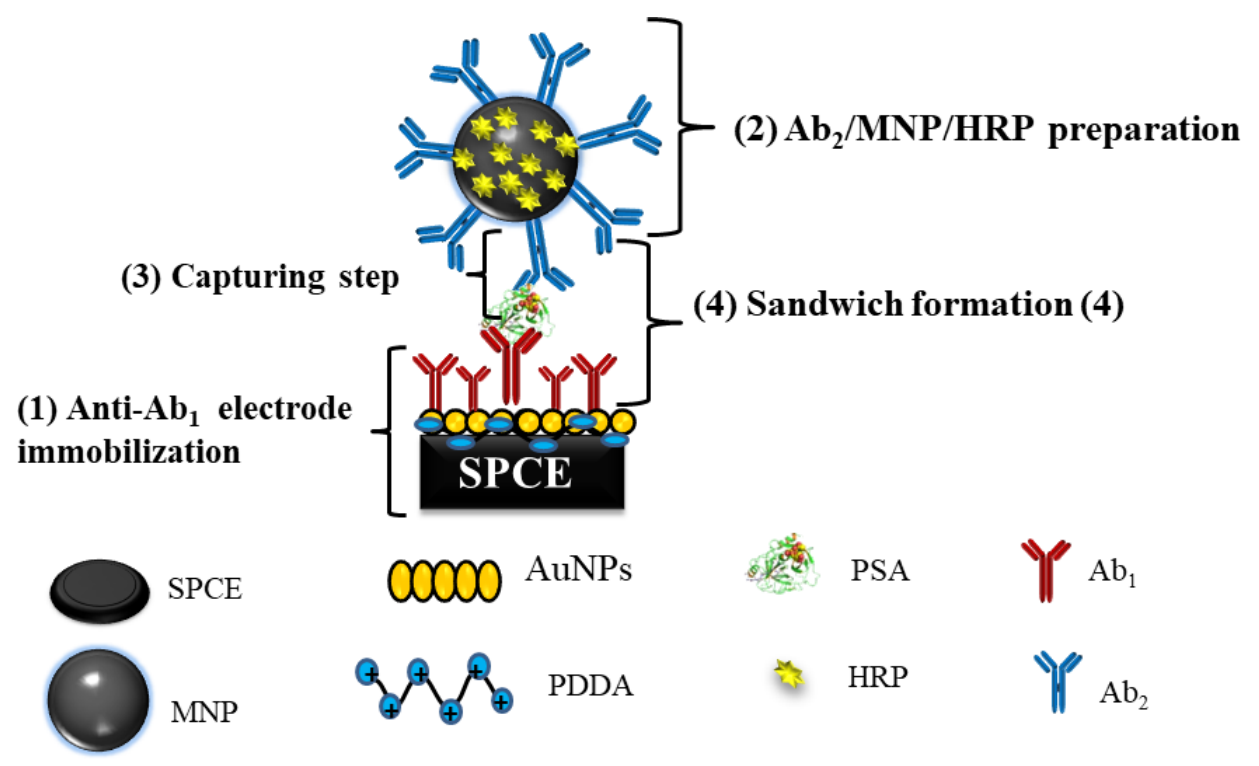

Figure 6: Schematic illustration of the fabrication of sandwich-type electrochemical immunosensors (IN $\mu$-SPCEs). 
The first step included the deposition of a bilayer of poly(diallyldimethylammonium) (PDDA) and gold nanoparticles (AuNPs) decorated with glutathione, as illustrated in Figure 7. An aliquot of $5 \mu \mathrm{L}$ of $2.0 \mathrm{mg} \cdot \mathrm{mL}^{-1}$ of PDDA was added to each working electrode and kept for $20 \mathrm{~min}$. The electrode surface was rinsed with Millipore water to remove excess of reagents. Then, $5.0 \mu \mathrm{L}$ of gold nanoparticles modified with glutathione (AuNP-GSH, $46.68 \mu \mathrm{g} \cdot \mathrm{mL}^{-1}$ ) were dripped on the electrode and left for a period of $20 \mathrm{~min}$. The carboxyl-terminated AuNPGSH provided a chemical group suitable for covalent binding. Next, a volume of $5 \mu \mathrm{L}$ EDC/NHS $\left(0.4 \mathrm{~mol} \cdot \mathrm{L}^{-1} \mathrm{EDC}\right.$ and $0.1 \mathrm{~mol} \cdot \mathrm{L}^{-1} \mathrm{NHS}$ ) in water was added on the surface of IN $\mu$ SPCEs and kept for $10 \mathrm{~min}$ to activate the carboxyl groups from AuNP-GSH, therefore ensuring a stable covalent binding to the antibodies. The primary monoclonal antibodies (Ab1) were adsorbed on the electrode by adding $5 \mu \mathrm{L}$ of a $10 \mu \mathrm{g} \cdot \mathrm{mL}^{-1}$ solution in PBS 7.0, with adsorption occurring overnight. The electrodes were then washed with $1.0 \mathrm{~mL}$ PBS and incubated with $5 \mu \mathrm{L}$ of bovine serum albumin (BSA) $(2 \% \mathrm{w} / \mathrm{w})$ diluted in PBS to avoid non-specific binding (NBS). Each step of the modification was monitored with polarization-modulated infrared reflection absorption spectroscopy (PM-IRRAS, see Figure S1F in Supporting Information File 1). The microfluidic cell was set up, and the electrodes were insulated using a polystyrene card with double-sided adhesive. The double-sided tape was used to delimit the electroactive area, which was fixed on the reference electrode under the arrangement of working electrodes and the auxiliary electrode. Also, the double-sided tape allowed for sealing of the microfluidic system.
The second step of the preparation of the sandwich immunosensors consisted in forming the bioconjugate complex of $\mathrm{Ab}_{2}$ and HRP ( $\mathrm{Ab}_{2}$-MNP-HRP), as described by Uliana and co-workers [58]. Briefly, $2.0 \mathrm{~mL}$ (stock solution: $10 \mathrm{mg}$ particles $\cdot \mathrm{mL}^{-1}$ ) of MNPs were placed in microtubes, which were then washed with $500 \mu \mathrm{L}$ of $0.05 \mathrm{~mol} \cdot \mathrm{L}^{-1}$ MES buffer at $\mathrm{pH} 5.2$ and separated magnetically. Later, the supernatant was discarded and washed thrice to give a final particle concentration of $40 \mathrm{mg} \cdot \mathrm{mL}^{-1}$. A $3 \mathrm{mg} \cdot \mathrm{mL}^{-1}$ solution of EDC/NHS in $0.05 \mathrm{~mol} \cdot \mathrm{L}^{-1}$ MES buffer at $\mathrm{pH} 5.2$ was added to the washed MNPs. It was shaken on a vortex-type stirrer for $5 \mathrm{~min}$ and on a rotary shaker for $30 \mathrm{~min}$. Immediately after shaking, the particles were magnetically separated and washed with MES buffer again. The supernatant was then removed, and the washing procedure was repeated twice again. Subsequently, $250 \mu \mathrm{L}$ of $\mathrm{Ab}_{2}$ were added to the solution with a final concentration of $10 \mu \mathrm{g} \cdot \mathrm{mL}^{-1}$. The solution was vortexed and shaken on a custom-made rotary shaker for $24 \mathrm{~h}$ at room temperature. At this point, the solution was magnetically separated and washed with $600 \mu \mathrm{L}$ PBS/ $0.05 \%$ Tween 20 buffer $\mathrm{pH} 7.4$.

HRP was conjugated to the MNPs by adding $500 \mu \mathrm{L}$ of $1.2 \mathrm{mg} \cdot \mathrm{mL}^{-1}$ of the enzyme to the $\mathrm{Ab}_{2}$-MNP complex. The mixture was left overnight on a rotary shaker. After $18 \mathrm{~h}$ of stirring, the bioconjugate complex was magnetically separated and then washed with $600 \mu \mathrm{L}$ of PBS/0.05\% Tween-20 and $0.1 \%$ BSA (four-fold). Later, $1.0 \mathrm{~mL}$ of glycine $1.0 \mathrm{~mol} \cdot \mathrm{L}^{-1} \mathrm{pH} 8$ was added to the solution. The solution was vortexed and stirred for $30 \mathrm{~min}$ at room temperature, followed by washing with

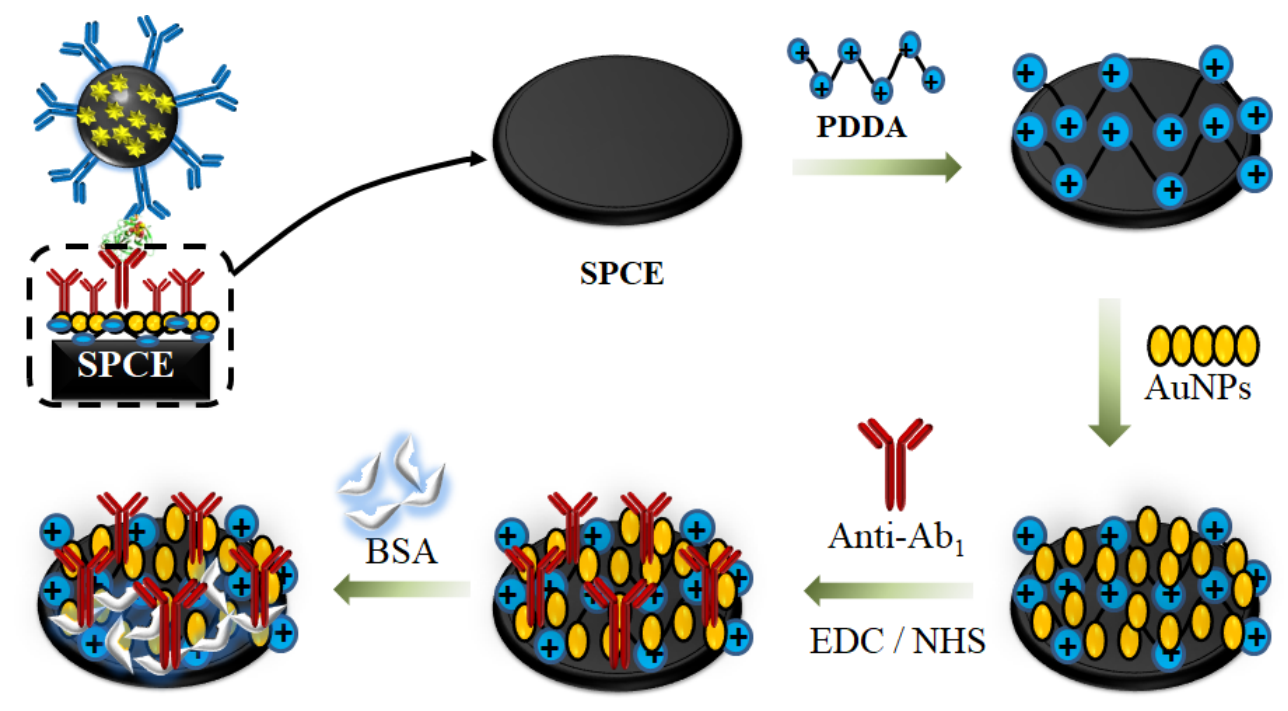

Figure 7: Electrode modification with $10 \mu \mathrm{g} \cdot \mathrm{mL}^{-1}$ monoclonal antibody (Ab 1$)$ using $5 \mu \mathrm{L}$ of $2 \mathrm{mg} \cdot \mathrm{mL}^{-1} \mathrm{PDDA}$ and $5 \mu \mathrm{L}$ of AuNP-GSH. To activate the carboxyl groups from AuNP-GSH and ensure a stable covalent binding of antibodies, EDC/NHS was used $\left(0.4 \mathrm{~mol} \cdot \mathrm{L}^{-1} \mathrm{EDC}\right.$ and $\left.0.1 \mathrm{~mol} \cdot \mathrm{L}^{-1} \mathrm{NHS}\right)$. The electrodes were washed with $1.0 \mathrm{~mL}$ of PBS buffer $\mathrm{pH} 7.4$ and incubated with $5 \mu \mathrm{L}$ of bovine serum albumin (BSA) (2\% w/w) diluted in phosphate-buffered saline (PBS), to avoid non-specific binding 
$0.05 \%$ PBS/Tween-20 buffer, pH 7.4 and $2 \%$ BSA; and magnetic separation. Finally, the bioconjugate complex was resuspended with $250 \mu \mathrm{L}$ of $0.05 \%$ PBS-Tween/20 buffer of $\mathrm{pH} 7.4$ and $2 \%$ BSA giving a final particle concentration of $5 \mathrm{mg} \cdot \mathrm{mL}^{-1}$. These steps are summarized in Figure 8.

In the third step, shown in Figure 9, $20 \mu \mathrm{L}$ of $\mathrm{Ab}_{2}$-MNP-HRP were added to $320 \mu \mathrm{L}$ PBS buffer at $\mathrm{pH}$ 7.4. For the standard calibration, $20 \mu \mathrm{L}$ of the antigen-enriched calf serum were added to the composite bioconjugate complex mixture. The mixture was then incubated at $37^{\circ} \mathrm{C}$ for $30 \mathrm{~min}$, and dilutions were required to decrease the protein concentration. The devices were also evaluated with real samples, including culture medium of cancerous and control cells (lineage of LNCap and PNT-2 cells, respectively). The cell lines PNT-2 and
LNCap were acquired from the Banco de Células do Rio de Janeiro (BCRJ, Rio de Janeiro, Brazil). The samples were diluted to a 1:30000 ratio. The resulting conjugate, $\mathrm{Ab}_{2}-\mathrm{MNP}-$ HRP-protein, was magnetically separated and washed with $400 \mu \mathrm{L}$ of $0.5 \% \mathrm{BSA}$ and $20 \mathrm{~mol} \cdot \mathrm{L}^{-1}$ of PBS buffer $\mathrm{pH} 7.4$. It was then resuspended to $125 \mu \mathrm{L}$.

In the fourth and last step, the bioconjugate complex was used to form the sandwich-type immunosensor, with $125 \mu \mathrm{L}$ of the final solution used in the immunoassay to fill a $100 \mu \mathrm{L}$ sample loop. This was performed in a microfluidic system with a flow rate of $100 \mu \mathrm{L} \cdot \mathrm{min}^{-1}$. The complex was injected with a syringe and the flow was stopped for $30 \mathrm{~min}$. In the amperometric detection step, the biomarker quantification was performed by an indirect method through the electrochemical response of the

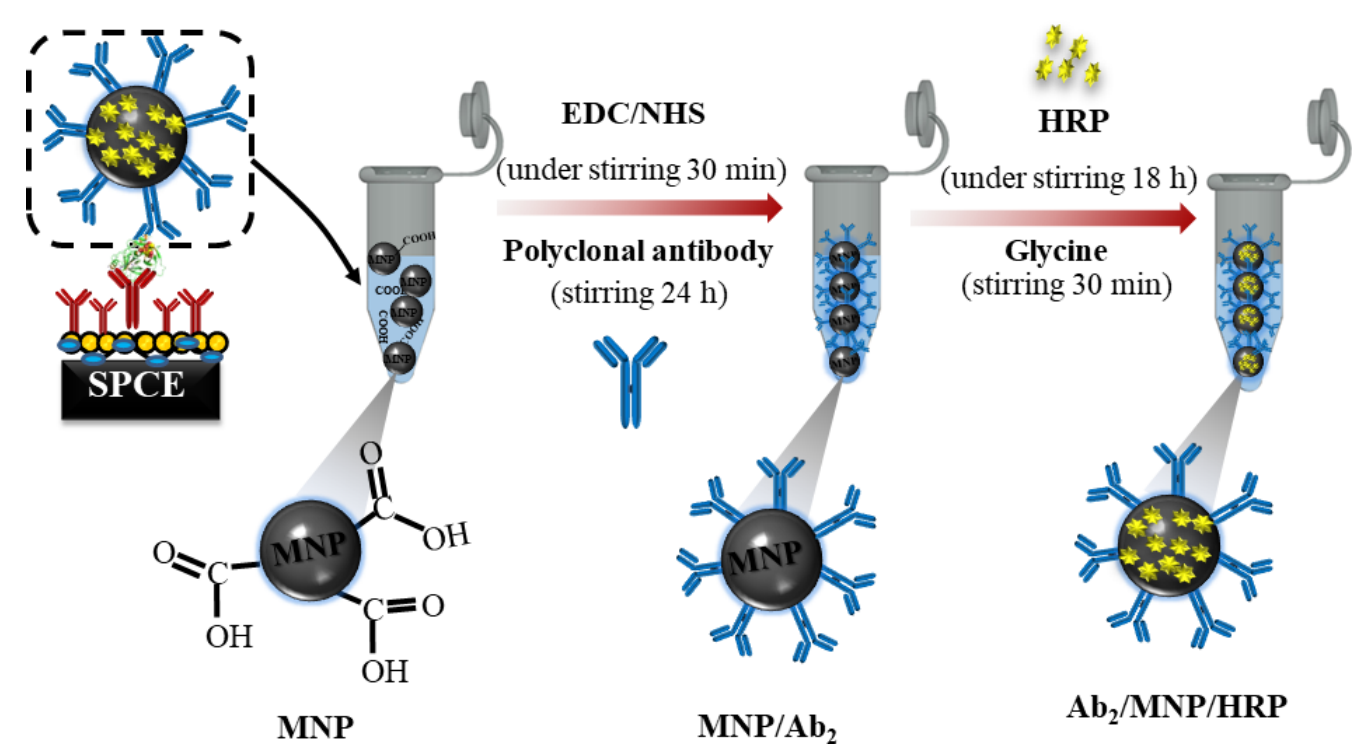

Figure 8: Preparation of the bioconjugate complex of $A b_{2}$ and $\mathrm{HRP}\left(\mathrm{Ab}_{2}-\mathrm{MNP}-\mathrm{HRP}\right)$.

\section{PSA capturing step}

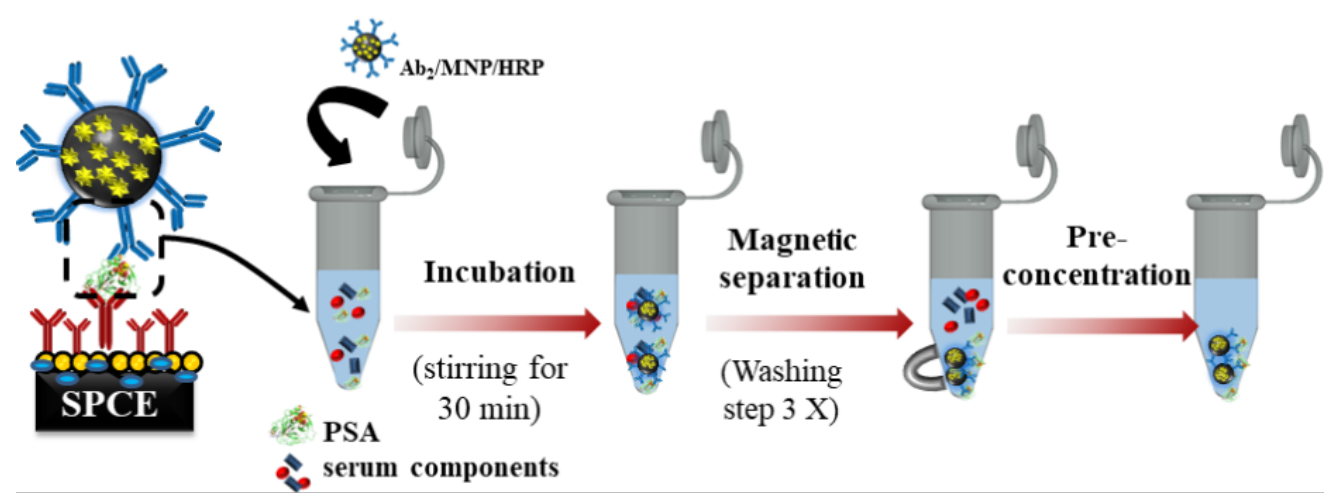

Figure 9: Illustration of the PSA capturing step. 
marker in the MNPs. It was monitored by injecting a solution containing $1.0 \mu \mathrm{mol} \cdot \mathrm{L}^{-1}$ of $\mathrm{H}_{2} \mathrm{O}_{2}$ and $10 \mu \mathrm{mol} \cdot \mathrm{L}^{-1}$ of hydroquinone (HQ) in the microfluidic system. The amperometric measurements were performed using a DropSens $\mu$ Stat 8000 multi-potentiostat/galvanostat. The multichannel screen-printed array contained eight working carbon electrodes combined with one pseudo-reference electrode $(\mathrm{Ag} / \mathrm{AgCl})$ and one auxiliary electrode (carbon). The microfluidic system was set up with an injection pump (NE-1000 programmable Single Syringe Pump, New Era Pump System, Farmingdale, USA) and an injection valve with a sample loop of $100 \mu \mathrm{L}$.

\section{Data treatment with information visualization methods}

The distinction of real samples is certainly challenging when various samples are analyzed, and false positives may occur. This has prompted researchers to use statistical and computational methods to treat the sensing data [31], in some cases with conjunction with machine learning approaches [31,59]. Here we employed multidimensional projection techniques based on linear and nonlinear multidimensional scaling (MDS) approaches such as principal component analysis (PCA) [60], Least squares projection (LSP) [61], Sammon's mapping (SM) [62] and interactive document mapping (IDMAP) [63] implemented in the software as projection explorer sensors (PExSensors) $[32,64]$. The amperogram data (current as a function of the time) were dimensionally reduced by PCA and FastMap [65] and then projected with PCA, LSP, IDMAP, and SM techniques. The dissimilarities between samples were converted to Euclidean distances with the whole rising current curves being transformed into single data points as observed in the projection plots. Three independent sets of measurements were utilized on this analysis. A full description of these techniques and PEx-sensors can be found in [32].

This type of analysis provides a map for pattern recognition among samples. It has been applied to biosensing data, mainly with IDMAP, which includes an algorithm to minimize the global error through a pairwise error function [63]. Herein, we combined the projections with parallel coordinates maps to perform feature selection with the exclusion of dimensions found to be deleterious for discrimination of similar data points, analogously to [66]. The performance upon applying the different projection techniques was evaluated by calculating the silhouette coefficient, $S$, defined as the average of the distances between each data instance and all other points belonging to the same group, and the minimum distance between each data instance and other instances belonging to other groups [67]. $S$ values vary between -1 and 1 . According to Rousseeuw, values above 0.71 indicate that a strong discrimination was obtained [68].

\section{Supporting Information}

Supporting Information features detailed information on the synthesis of magnetic iron oxide nanoparticles, electrode fabrication, and sample preparation. Also, the characterization of MNPs and electrode surfaces by using Fourier-transform infrared spectroscopy (FTIR), field-emission scanning electron microscopy (FE-SEM), energy-dispersive X-ray spectroscopy (EDX), and polarization-modulated infrared reflection absorption spectroscopy (PM-IRRAS, Figure S1) is described. The Silhouette coefficients calculated for IDMAP, Sammon's mapping (SM), principal component analysis (PCA), and least square projection (LSP) multidimensional projection techniques to analyze the PSA concentration of immunosensor before (All) and after (FS) feature selection (Figure S2) are provided as well. The parallel coordinates plot for PSA concentrations from 12.5 to $1111 \mathrm{fg} \cdot \mathrm{mL}^{-1}$ are given in Figure $\mathrm{S} 3$, while plots of three multidimensional projection techniques, i.e., PCA, LSP, and SM are shown in Figure S4.

\section{Supporting Information File 1}

Additional procedures and figures.

[https://www.beilstein-journals.org/bjnano/content/ supplementary/2190-4286-10-210-S1.pdf]

\section{Acknowledgements}

The authors gratefully acknowledge financial support provided by CAPES (Finance Code No\# 001), CNPq (Proc. No. 308570/ 2018-9), and FAPESP (2013/14262-7, 2016/00991-5).

\section{ORCID ${ }^{\circledR}$ iDs}

Camila A. Proença - https://orcid.org/0000-0001-8438-4651 Tayane A. Freitas - https://orcid.org/0000-0002-2086-5576 Thaísa A. Baldo - https://orcid.org/0000-0002-3212-0571 Frederico L. F. Soares - https://orcid.org/0000-0002-8555-2095 Ronaldo C. Faria - https://orcid.org/0000-0003-1094-9597

\section{References}

1. Saini, S. Cell. Oncol. 2016, 39, 97-106. doi:10.1007/s13402-016-0268-6

2. Liedtke, R. J.; Batjer, J. D. Clin. Chem. 1984, 30, 649-652.

3. Wang, X.; Zhao, M.; Nolte, D. D.; Ratliff, T. L. Biosens. Bioelectron. 2011, 26, 1871-1875. doi:10.1016/j.bios.2010.02.009

4. Ellis, W. J.; Vessella, R. L.; Noteboom, J. L.; Lange, P. H.; Wolfert, R. L.; Rittenhouse, H. G. Urol. 1997, 50, 573-579. doi:10.1016/s0090-4295(97)00251-3

5. Panini, N. V.; Messina, G. A.; Salinas, E.; Fernández, H.; Raba, J. Biosens. Bioelectron. 2008, 23, 1145-1151. doi:10.1016/j.bios.2007.11.003 
6. Zani, A.; Laschi, S.; Mascini, M.; Marrazza, G. Electroanalysis 2011, 23, 91-99. doi:10.1002/elan.201000486

7. Meng, W.; Zhang, W.; Zhang, J.; Chen, X.; Zhang, Y. Anal. Methods 2019, 11, 2183-2189. doi:10.1039/c9ay00064j

8. Liu, L.; Zhao, G.; Dong, X.; Li, X.; Wei, Q.; Cao, W. Anal. Methods 2018, 10, 4917-4925. doi:10.1039/c8ay01533c

9. Kim, D.-J.; Lee, N.-E.; Park, J.-S.; Park, I.-J.; Kim, J.-G.; Cho, H. J. Biosens. Bioelectron. 2010, 25, 2477-2482. doi:10.1016/j.bios.2010.04.013

10. Pankhurst, Q. A.; Connolly, J.; Jones, S. K.; Dobson, J. J. Phys. D: Appl. Phys. 2003, 36, R167-R181. doi:10.1088/0022-3727/36/13/201

11. Wen, W.; Yan, X.; Zhu, C.; Du, D.; Lin, Y. Anal. Chem. (Washington, DC, U. S.) 2017, 89, 138-156. doi:10.1021/acs.analchem.6b04281

12. Liébana, S.; Brandão, D.; Alegret, S.; Pividori, M. I. Anal. Methods 2014, 6, 8858-8873. doi:10.1039/c4ay01373e

13. Proença, C. A.; Baldo, T. A.; Freitas, T. A.; Materón, E. M.; Wong, A.; Durán, A. A.; Melendez, M. E.; Zambrano, G.; Faria, R. C. Anal. Chim. Acta 2019, 1071, 59-69. doi:10.1016/j.aca.2019.04.047

14. Aqil, A.; Vasseur, S.; Duguet, E.; Passirani, C.; Benoît, J. P.; Roch, A.; Müller, R.; Jérôme, R.; Jérôme, C. Eur. Polym. J. 2008, 44, 3191-3199. doi:10.1016/j.eurpolymj.2008.07.011

15. Hatch, G. P.; Stelter, R. E. J. Magn. Magn. Mater. 2001, 225, 262-276. doi:10.1016/s0304-8853(00)01250-6

16. Park, J.; Lim, H. B. Food Chem. 2014, 160, 112-117. doi:10.1016/j.foodchem.2014.03.047

17. Teja, A. S.; Koh, P.-Y. Prog. Cryst. Growth Charact. Mater. 2009, 55, 22-45. doi:10.1016/j.pcrysgrow.2008.08.003

18. Ferreira, G. R.; Segura, T.; de Souza, F. G., Jr.; Umpierre, A. P.; Machado, F. Eur. Polym. J. 2012, 48, 2050-2069. doi:10.1016/j.eurpolymj.2012.09.003

19. Mascolo, M.; Pei, Y.; Ring, T. Materials 2013, 6, 5549-5567. doi:10.3390/ma6125549

20. Yu, S.; Chow, G. M. J. Mater. Chem. 2004, 14, 2781-2786. doi:10.1039/b404964k

21. Neves, J. S.; de Souza, F. G., Jr.; Suarez, P. A. Z.; Umpierre, A. P.; Machado, F. Macromol. Mater. Eng. 2011, 296, 1107-1118. doi:10.1002/mame.201100050

22. Ahmadi, A.; Shirazi, H.; Pourbagher, N.; Akbarzadeh, A.; Omidfar, K. Mol. Biol. Rep. 2014, 41, 1659-1668. doi:10.1007/s11033-013-3014-4

23. Li, J.; Gao, H.; Chen, Z.; Wei, X.; Yang, C. F. Anal. Chim. Acta 2010, 665, 98-104. doi:10.1016/j.aca.2010.03.020

24. Tang, D.; Yuan, R.; Chai, Y. J. Phys. Chem. B 2006, 110 , 11640-11646. doi:10.1021/jp060950s

25. Zhuo, Y.; Yuan, P.-X.; Yuan, R.; Chai, Y.-Q.; Hong, C.-L. Biomaterials 2009, 30, 2284-2290. doi:10.1016/j.biomaterials.2009.01.002

26. Chikkaveeraiah, B. V.; Mani, V.; Patel, V.; Gutkind, J. S.; Rusling, J. F. Biosens. Bioelectron. 2011, 26, 4477-4483. doi:10.1016/j.bios.2011.05.005

27. Chuah, K.; Lai, L. M. H.; Goon, I. Y.; Parker, S. G.; Amal, R.; Justin Gooding, J. Chem. Commun. 2012, 48, 3503. doi:10.1039/c2cc30512g

28. Li, H.; Wei, Q.; He, J.; Li, T.; Zhao, Y.; Cai, Y.; Du, B.; Qian, Z.; Yang, M. Biosens. Bioelectron. 2011, 26, 3590-3595. doi:10.1016/j.bios.2011.02.006

29. Tang, D.; Yuan, R.; Chai, Y. Anal. Chem. 2008, 80, 1582-1588. doi:10.1021/ac702217m
30. Beveridge, J. S.; Stephens, J. R.; Williams, M. E. Annu. Rev. Anal. Chem. 2011, 4, 251-273. doi:10.1146/annurev-anchem-061010-114041

31. Paulovich, F. V.; De Oliveira, M. C. F.; Oliveira, O. N., Jr. ACS Sens. 2018, 3, 1433-1438. doi:10.1021/acssensors.8b00276

32. Paulovich, F. V.; Moraes, M. L.; Maki, R. M.; Ferreira, M.; Oliveira Jr., O. N.; de Oliveira, M. C. F. Analyst 2011, 136, 1344. doi:10.1039/c0an00822b

33. Moraes, M. L.; Petri, L.; Oliveira, V.; Olivati, C. A.; de Oliveira, M. C. F.; Paulovich, F. V.; Oliveira, O. N., Jr.; Ferreira, M. Sens. Actuators, B 2012, 166-167, 231-238. doi:10.1016/j.snb.2012.02.046

34. Thapa, A.; Soares, A. C.; Soares, J. C.; Awan, I. T.; Volpati, D.; Melendez, M. E.; Fregnani, J. H. T. G.; Carvalho, A. L.; Oliveira, O. N., Jr. ACS Appl. Mater. Interfaces 2017, 9, 25878-25886. doi:10.1021/acsami.7b07384

35. Thompson, M.; Ellison, S. L. R.; Wood, R. Pure Appl. Chem. 2002, 74, 835-855. doi:10.1351/pac200274050835

36. Manso, J.; Mena, M. L.; Yáñez-Sedeño, P.; Pingarrón, J. J. Electroanal. Chem. 2007, 603, 1-7. doi:10.1016/j.jelechem.2007.02.004

37. Liu, S.; Zhang, X.; Wu, Y.; Tu, Y.; He, L. Clin. Chim. Acta 2008, 395, 51-56. doi:10.1016/j.cca.2008.04.031

38. Barton, A. C.; Davis, F.; Higson, S. P. J. Anal. Chem. (Washington, DC, U. S.) 2008, 80, 6198-6205. doi:10.1021/ac800491m

39. Qu, B.; Chu, X.; Shen, G.; Yu, R. Talanta 2008, 76, 785-790. doi:10.1016/j.talanta.2008.04.026

40. Escamilla-Gómez, V.; Hernández-Santos, D.; González-García, M. B.; Pingarrón-Carrazón, J. M.; Costa-García, A. Biosens. Bioelectron. 2009, 24, 2678-2683. doi:10.1016/j.bios.2009.01.043

41. Zheng, Y.; Chen, H.; Liu, X.-P.; Jiang, J.-H.; Luo, Y.; Shen, G.-L.; Yu, R.-Q. Talanta 2008, 77, 809-814. doi:10.1016/j.talanta.2008.07.038

42. Huang, L.; Reekmans, G.; Saerens, D.; Friedt, J.-M.; Frederix, F.; Francis, L.; Muyldermans, S.; Campitelli, A.; Hoof, C. V. Biosens. Bioelectron. 2005, 21, 483-490. doi:10.1016/j.bios.2004.11.016

43. Chu, Y.; Wang, H.; Ma, H.; Wu, D.; Du, B.; Wei, Q. RSC Adv. 2016, 6, 84698-84704. doi:10.1039/c6ra13841a

44. Feng, J.; Li, Y.; Li, M.; Li, F.; Han, J.; Dong, Y.; Chen, Z.; Wang, P.; Liu, H.; Wei, Q. Biosens. Bioelectron. 2017, 91, 441-448. doi:10.1016/j.bios.2016.12.070

45. Arya, S. K.; Bhansali, S. Biosens. J. 2011, 1, 102.

46. Jang, H. D.; Kim, S. K.; Chang, H.; Choi, J.-W. Biosens. Bioelectron. 2015, 63, 546-551. doi:10.1016/j.bios.2014.08.008

47. Mao, K.; Wu, D.; Li, Y.; Ma, H.; Ni, Z.; Yu, H.; Luo, C.; Wei, Q.; Du, B. Anal. Biochem. 2012, 422, 22-27. doi:10.1016/j.ab.2011.12.047

48. Li, Y.; Han, J.; Chen, R.; Ren, X.; Wei, Q. Anal. Biochem. 2015, 469, 76-82. doi:10.1016/j.ab.2014.09.022

49. Adel Ahmed, H.; Azzazy, H. M. E. Biosens. Bioelectron. 2013, 49, 478-484. doi:10.1016/j.bios.2013.05.058

50.Shi, H.-W.; Zhao, W.; Liu, Z.; Liu, X.-C.; Wu, M.-S.; Xu, J.-J.; Chen, H.-Y. Talanta 2016, 154, 169-174. doi:10.1016/j.talanta.2016.03.059

51. Fan, D.; Li, N.; Ma, H.; Li, Y.; Hu, L.; Du, B.; Wei, Q. Biosens. Bioelectron. 2016, 85, 580-586. doi:10.1016/j.bios.2016.05.063

52. Kavosi, B.; Salimi, A.; Hallaj, R.; Moradi, F. Biosens. Bioelectron. 2015, 74, 915-923. doi:10.1016/j.bios.2015.07.064 
53. Salimi, A.; Kavosi, B.; Fathi, F.; Hallaj, R. Biosens. Bioelectron. 2013, 42, 439-446. doi:10.1016/j.bios.2012.10.053

54. Soares, J. C.; Soares, A. C.; Pereira, P. A. R.; Rodrigues, V. da C.; Shimizu, F. M.; Melendez, M. E.; Scapulatempo Neto, C.;

Carvalho, A. L.; Leite, F. L.; Machado, S. A. S.; Oliveira, O. N. Phys. Chem. Chem. Phys. 2016, 18, 8412-8418. doi:10.1039/c5cp07121f

55. Soares, A. C.; Soares, J. C.; Shimizu, F. M.; Melendez, M. E.; Carvalho, A. L.; Oliveira, O. N., Jr. ACS Appl. Mater. Interfaces 2015, 7, 25930-25937. doi:10.1021/acsami.5b08666

56. Kuriyama, M.; Obata, K.; Miyagawa, Y.; Nishikawa, E.; Koide, T.; Takeda, A.; Komeda, Y.; Kanbayashi, T.; Nakano, M.; Miyake, K. Int. J. Urol. 1996, 3, 462-467. doi:10.1111/j.1442-2042.1996.tb00577.x

57. Afonso, A. S.; Uliana, C. V.; Martucci, D. H.; Faria, R. C. Talanta 2016, 146, 381-387. doi:10.1016/j.talanta.2015.09.002

58. Uliana, C. V.; Peverari, C. R.; Afonso, A. S.; Cominetti, M. R.; Faria, R. C. Biosens. Bioelectron. 2018, 99, 156-162. doi:10.1016/j.bios.2017.07.043

59. Shimizu, F. M.; Pasqualeti, A. M.; Todão, F. R.; de Oliveira, J. F. A.; Vieira, L. C. S.; Gonçalves, S. P. C.; da Silva, G. H.; Cardoso, M. B.; Gobbi, A. L.; Martinez, D. S. T.; Oliveira, O. N., Jr.; Lima, R. S. ACS Sens. 2018, 3, 716-726. doi:10.1021/acssensors.8b00056

60. Jolliffe, I. T. Principal Component Analysis and Factor Analysis. Principal Component Analysis; Springer Series in Statistics; Springer New York: New York, NY, U.S.A., 1986; pp 115-128. doi:10.1007/978-1-4757-1904-8_7

61. Paulovich, F. V.; Nonato, L. G.; Minghim, R.; Levkowitz, H. IEEE Trans. Visualization Comput. Graphics 2008, 14, 564-575. doi:10.1109/tvcg.2007.70443

62. Sammon, J. W. IEEE Trans. Comput. 1969, C-18, 401-409. doi:10.1109/t-c.1969.222678

63. Minghim, R.; Paulovich, F. V.; de Andrade Lopes, A. Content-based text mapping using multi-dimensional projections for exploration of document collections. In Proceedings of the Society of Photo-Optical Instrumentation Engineers (SPIE), San Jose, CA, U.S.A.; 60600 S. doi:10.1117/12.650880

64. Soares, T.; Uliana, C. H.; Zanoni, J. N. Glutathione promoves myenteric neuroprotection in the jejunum of diabetic rats. In Proceedings of the International neurogastroenterology and motility meeting, 2012, Bologna, Italy; pp 43-190. doi:10.1111/j.1365-2982.2012.01997.x

65. Faloutsos, C.; Lin, K.-I. FastMap: A fast algorithm for indexing, data-mining and visualization of traditional and multimedia datasets. In Proceedings of the 1995 ACM SIGMOD international conference on Management of data, San Jose, U.S.A.; pp 163-174. doi:10.1145/568271.223812

66. Daikuzono, C. M.; Shimizu, F. M.; Manzoli, A.; Riul, A., Jr.; Piazzetta, M. H. O.; Gobbi, A. L.; Correa, D. S.; Paulovich, F. V.; Oliveira, O. N., Jr. ACS Appl. Mater. Interfaces 2017, 9, 19646-19652. doi:10.1021/acsami.7b04252

67. Tan, P.-N.; Steinbach, M.; Kumar, V. Instructor's Solution Manual. Introduction to Data Mining; Pearson Addison-Wesley, 2006.

68. Rousseeuw, P. J. J. Comput. Appl. Math. 1987, 20, 53-65. doi:10.1016/0377-0427(87)90125-7

\section{License and Terms}

This is an Open Access article under the terms of the Creative Commons Attribution License (http://creativecommons.org/licenses/by/4.0). Please note that the reuse, redistribution and reproduction in particular requires that the authors and source are credited.

The license is subject to the Beilstein Journal of Nanotechnology terms and conditions: (https://www.beilstein-journals.org/bjnano)

The definitive version of this article is the electronic one which can be found at:

doi:10.3762/bjnano. 10.210 